\title{
Key role of short-chain fatty acids in epithelial barrier failure during ruminal acidosis
}

\author{
Svenja Meissner, ${ }^{*}$ Franziska Hagen, ${ }^{*}$ Carolin Deiner, ${ }^{*}$ Dorothee Günzel,† Gabriele Greco, ${ }^{*}$ Zanming Shen,‡ \\ and Jörg R. Aschenbach*1 \\ *Institute of Veterinary Physiology, Freie Universität Berlin, D-14163 Berlwin, Germany \\ †Institute of Clinical Physiology, Charité-Universitätsmedizin Berlin, D-12203 Berlin, Germany \\ łLaboratory of Animal Physiology and Biochemistry, Nanjing Agricultural University, Nanjing 210095, China
}

\begin{abstract}
Subacute ruminal acidosis is induced by high concentrations of short-chain fatty acids (SCFA, mainly acetate, propionate, and butyrate) that release protons to decrease the $\mathrm{pH}$ of the ruminal digesta. This low $\mathrm{pH}$, in turn, is thought to damage epithelial barrier function. The present study applied a model of simulated ruminal acidosis ex vivo to investigate if SCFA directly contribute to epithelial barrier failure beyond their role as proton donors. Epithelial tissues from the rumen of slaughtered sheep were mounted in Ussing chambers and incubated under 3 different conditions. Two groups were incubated in the absence of SCFA at mucosal $\mathrm{pH}$ 6.1 (control) and $\mathrm{pH} 5.1$, respectively, for $7 \mathrm{~h}$. A third group was first incubated in a mucosal solution containing $100 \mathrm{~m} M \mathrm{SCFA}$ at $\mathrm{pH} 5.1$ for $2 \mathrm{~h}$ and, thereafter, in a mucosal solution without SCFA at $\mathrm{pH} 6.1$ for the remaining $5 \mathrm{~h}$. Transepithelial conductance $\left(G_{\mathrm{t}}\right)$, shortcircuit current $\left(I_{\mathrm{sc}}\right)$, and fluorescein fluxes were determined. After $7 \mathrm{~h}$ of incubation, the expression levels of claudin-1, claudin-4, claudin-7, and occludin were measured by quantitative reverse-transcription PCR and Western blot. Furthermore, the local distribution of these tight junction (TJ) proteins was examined by confocal laser scanning microscopy. A 7-h incubation at $\mathrm{pH} 5.1$ in the absence of SCFA did not influence either $G_{\mathrm{t}}$ or fluorescein flux rates of ruminal tissues ex vivo compared with the control. In contrast, incubation at $\mathrm{pH} 5.1$ with SCFA for only $2 \mathrm{~h}$ induced increases in $G_{\mathrm{t}}$ and fluorescein flux rates that continued even after tissues were returned back to $\mathrm{pH}$ 6.1. Expression analysis showed that $\mathrm{pH} 5.1$ without SCFA for $7 \mathrm{~h}$ induced no changes in mRNA expression of claudin-1, claudin-4, claudin- 7 , and occludin and a selective decrease in protein expression of only claudin- 4 compared with the
\end{abstract}

Received November 6, 2016.

Accepted April 8, 2017.

${ }^{1}$ Corresponding author: joerg.aschenbach@fu-berlin.de control. However, a 2-h incubation at $\mathrm{pH} 5.1$ in the presence of SCFA decreased the mRNA-expression of claudin-7, as well as the protein expression of claudin-4, claudin-7, and occludin. The decreased expression of these TJ proteins in the group incubated with SCFA was also evident in immunohistochemistry. Immunohistochemistry additionally evidenced a considerable retraction of all tested TJ proteins out of the TJ in that group. We conclude that a low mucosal $\mathrm{pH}$ of 5.1 is tolerated well by ruminal epithelia for several hours. However, a low pH in combination with SCFA induces damage to the TJ and disturbs barrier function, which is not immediately reversible upon the removal of the acidotic insult.

Key words: ruminal epithelium, subacute ruminal acidosis, tight junction, short-chain fatty acid

\section{INTRODUCTION}

Subacute ruminal acidosis is triggered by an excessive intake of highly fermentable feedstuffs as commonly fed to high-yielding dairy cows (Kleen et al., 2003). In the course of this disease, short-chain fatty acids (SCFA) accumulate in the rumen due to rapid microbial breakdown of carbohydrates. On the one hand, increased production of acetate $(45-70 \%)$, propionate (15-40\%), and butyrate (5-20\%; Bergman, 1990; Aschenbach et al., 2011) is essential to meet the increased energy and glucose demand during lactation (Bugaut, 1987; Aschenbach et al., 2010). On the other hand, an increased ruminal concentration of SCFA leads to a decrease in ruminal $\mathrm{pH}$ to values below 5.5. The latter can cause an impairment of the epithelial barrier (Penner et al., 2009; Aschenbach et al., 2011). Histological changes such as parakeratosis indicate a disturbed organization of the epithelium. The epithelial barrier becomes permeable for bacteria and endotoxin (Szemeredy and Raul, 1976), which after translocation can cause liver abscesses and laminitis, followed by a decrease in milk yield, and in severe cases, the animal has to be culled (Nocek, 1997; Tadepalli et al., 2009). 
Transmembrane tight junction $(\mathbf{T J})$ proteins are crucial structures to prevent the translocation of noxious substrates across the epithelial layer. These proteins form circumferential cell-cell contacts that limit the permeability along the paracellular pathway in epithelia and endothelia (Balda and Matter, 2003). Tight junction proteins are subdivided in 2 families; one composed of occludin, tricellulin, and Marvel D3 (Raleigh et al., 2010), whereas the other includes the currently 27 known claudins (Morita et al., 1999; Mineta et al., 2011). Claudins regulate epithelial barrier function in different tissues mostly as sealing (i.e., tightening, components); however, some of them also form pores for charge and size-selective paracellular diffusion. Numerous studies have demonstrated the relevance of deficient TJ protein expression and distribution related to various epithelial diseases (Markov et al., 2015). For example, impaired barrier function and increased loss of solutes and water into the intestinal lumen has been demonstrated in inflammatory bowel disease, which was based on changes in epithelial TJ structure and a reduced tight junctional complexity (Heller et al., 2005; Zeissig et al., 2007). In the stratified squamous epithelium of the rumen, claudins form a barrier against the passive paracellular entry of substances from the ruminal content. So far, claudin- 1 , claudin- 4 , claudin-7, and occludin have been identified as relevant TJ components in ruminal epithelia (Stumpff et al., 2011). Whereas claudin-1 and claudin-4 are clearly barrier-forming claudins (Van Itallie et al., 2001; Furuse et al., 2002), the role of claudin- 7 is not as well defined. Nonetheless, changes in claudin-7 expression are involved in epithelia dysfunction. For example, the occurrence of typical skin lesions in psoriasis, involving parakeratosis, is linked to a low expression level of claudin-7 (Kirschner et al., 2009) and intestine-specific claudin-7 knockout mice showed increased intestinal permeability and inflammation of mucosal structures (Tanaka et al., 2015).

The relevance of epithelial TJ disruption in the rumen was previously demonstrated in goats (Liu et al., 2013). Goats fed a high-grain diet in vivo showed a decrease in ruminal $\mathrm{pH}$ from 6.1 to 5.3 in combination with alterations in ruminal epithelial structure. The altered ruminal epithelial structure, in turn, could be related to a downregulation of claudin- 4 and occludin mRNA and protein expression as well as to a redistribution of claudin-1, claudin-4, and occludin (Liu et al., 2013). We had demonstrated previously that similar barrier failure can be induced in isolated ruminal epithelia ex vivo by $\sim 1 \mathrm{~h}$ acidification of the mucosal incubation solution to $\mathrm{pH} 5.1$ in the presence of $39 \mathrm{mM}$ SCFA (Aschenbach and Gäbel, 2000). In a subsequent trial, however, a similar acidification to $\mathrm{pH} 5.2$ for $1.5 \mathrm{~h}$ ex vivo led to no changes in ruminal epithelial permeability when SCFA were absent (Penner et al., 2010). Only when the acidic solution on the mucosal side was replaced by a solution with physiological luminal $\mathrm{pH}$, epithelia showed some minor degree of barrier failure during the recovery period (Penner et al., 2010). From these experimental findings, the hypothesis was generated (1) that the presence of SCFA crucially determines the degree of epithelial damage during an acidotic insult and (2) that the epithelial damage develops to its full extent after the acidotic insult when the $\mathrm{pH}$ is already back at physiological levels. To proof this hypothesis, the present study was designed to monitor the early events of barrier failure during a simulated ruminal acidosis ex vivo and to evaluate the changes in the expression and localization of TJ proteins underlying these early events. A special focus was to determine whether the presence of SCFA can aggravate the impairment in barrier function elicited by low $\mathrm{pH}$.

\section{MATERIALS AND METHODS}

\section{Animals and Tissue Preparation}

Sheep of both sexes were fed a hay-only diet for at least 2 wk before slaughtering. The animals had ad libitum access to water and lick stones. The sheep were stunned with a captive bolt gun and subsequently killed by exsanguination with following removal of the reticulo-rumen from the abdominal cavity. A $300-\mathrm{cm}^{2}$ piece of rumen wall was taken from the ventral sac and rinsed in standard buffered solution $(10 \mathrm{mM} \mathrm{NaCl}, 24$ $\mathrm{m} M \mathrm{NaHCO}_{3}, 0.6 \mathrm{mM} \mathrm{NaH} \mathrm{PO}_{4}, 2.4 \mathrm{mM} \mathrm{Na} \mathrm{HPO}_{4}$, $5.5 \mathrm{~m} M \mathrm{KCl}, 10 \mathrm{~m} M$ 2-( $N$-morpholino)ethanesulfonic acid, $1 \mathrm{~m} M$ L-glutamine, $10 \mathrm{~m} M$ glucose, $1 \mathrm{mM} \mathrm{CaCl}{ }_{2}$, $1.25 \mathrm{~m} M \mathrm{MgCl}_{2}, 100 \mathrm{~m} M$ Na-gluconate; $37^{\circ} \mathrm{C}, \mathrm{pH}$ 7.4). Afterward the epithelium was stripped from the muscle layer and cut into 5 strips. Tissue strips were transported in standard buffered solution gassed with carbogen $\left(95 \% \mathrm{O}_{2} / 5 \% \mathrm{CO}_{2}\right)$ at a temperature of $37^{\circ} \mathrm{C}$.

\section{Electrophysiological Measurement in Ussing Chambers}

Ruminal tissue strips were cut into squares of approximately $3 \times 3 \mathrm{~cm}$ size and each mounted between the 2 halves of a conventional Ussing chamber (Aschenbach and Gäbel, 2000). Both serosal und mucosal surfaces of the rumen were equilibrated in $16 \mathrm{~mL}$ of a standard buffered solution (for the composition, see the previous section) at $\mathrm{pH} 7.4$ for $30 \mathrm{~min}$. Afterward, the tissues were divided into 3 treatment groups with different mucosal incubation solutions. A first group was incubated at a mucosal pH 6.1 (group pH 6.1; control) 
and a second group at mucosal $\mathrm{pH} 5.1$ for $7 \mathrm{~h}$ (group $\mathrm{pH}$ 5.1). The $\mathrm{pH}$ of the 2 buffer solutions was adjusted by stepwise addition of gluconic acid to the standard buffered solution. The third group was first incubated in a mucosal solution containing $100 \mathrm{~m} M$ SCFA at $\mathrm{pH}$ 5.1 , followed by incubation in a standard buffered solution at $\mathrm{pH} 6.1$ (without SCFA) for the remaining 5 $\mathrm{h}$ [hereafter referred to as group $\mathrm{pH} 5.1$ (SCFA challenge)]. The SCFA-containing solution was of the same composition as the standard buffered solution, except that $100 \mathrm{~m} M \mathrm{Na}$-gluconate were replaced by a mixture of $60 \mathrm{~m} M$ Na-acetate, $30 \mathrm{~m} M$ Na-propionate, and 10 $\mathrm{m} M$ Na-butyrate (pH adjusted to $\mathrm{pH} 5.1$ using gluconic acid). During incubation, transepithelial conductance $\left(\boldsymbol{G}_{\mathrm{t}}\right)$ and short-circuit current $\left(\boldsymbol{I}_{\mathrm{sc}}\right)$ were continuously recorded (Aschenbach and Gäbel, 2000), and samples of incubation solution were collected for flux rate determination every hour (see below).

After $7 \mathrm{~h}$ of incubation, all tissues were removed from the Ussing chambers, split into 3 parts, and preserved in RNAlater (Thermo Fisher Scientific, Waltham MA), liquid $\mathrm{N}_{2}$, and $4 \%$ paraformaldehyde for quantitative real-time PCR (qPCR), Western blot, and immunohistochemistry, respectively.

\section{Fluorescein Flux Rates}

To measure mucosal-to-serosal fluorescein flux rates $\left(\boldsymbol{J}_{\mathrm{ms} \text {-fluor }}\right)$, sodium fluorescein was added to a final concentration of $0.1 \mathrm{~m} M$ to the incubation solution on the mucosal side of each tissue directly after the equilibration period. Addition of fluorescein solution was repeated after the mucosal SCFA-containing solution ( $\mathrm{pH}$ 5.1) had been exchanged by SCFA-free solution (pH 6.1) in the group $\mathrm{pH} 5.1$ (SCFA challenge) after 2 $\mathrm{h}$ of incubation. To determine the specific fluorescence intensity, $50-\mu \mathrm{L}$ samples were taken from the mucosal side of each tissue immediately after adding the fluorophore. Thereafter, $500-\mu \mathrm{L}$ samples were taken in hourly intervals from the serosal side of each chamber. The volume removed from the serosal side was replenished with fresh standard buffered solution. Fluorescence was measured in a plate reader at $490 \mathrm{~nm}$ excitation and $525 \mathrm{~nm}$ emission (EnSpire Multimode Plate Reader, Perkin Elmer, Waltham, MA). Flux rates were calculated by relating the fluorescence appearing at the serosal side to the specific fluorescence of the respective mucosal side.

\section{qPCR}

Total RNA was isolated using the Nucleo Spin RNA II kit (Macherey \& Nagel, Düren, Germany) and RNA concentration was measured with a nanophotometer (Implen, München, Germany). The integrity of the RNA was determined by running an on-chip gel electrophoresis using the RNA 6000 Nano Kit (Agilent, Santa Clara, CA). An aliquot of $400 \mathrm{ng}$ of isolated RNA served as a template for cDNA synthesis using the iScript cDNA Synthesis Kit (Bio-Rad Laboratories, Hercules, CA). The total reaction volume of $40 \mu \mathrm{L}$ was afterward diluted 1:10. Changes in mRNA expression of claudin-1, claudin-4, claudin-7, and occludin were evaluated by qPCR. Gene-specific primers and probes were designed from public database information (Table 1) and produced by MWG Eurofins Operon (Ebersberg, Germany). The qPCR was carried out on a thermocycler (ViiA7, Life Technologies, Carlsbad, CA) using a 40 cycle 2-step protocol $\left(20 \mathrm{~s}\right.$ at $60^{\circ} \mathrm{C}, 1 \mathrm{~s}$ at $\left.95^{\circ} \mathrm{C}\right)$ and iTaq Universal Probes Supermix (Bio-Rad Laboratories) as a ready-to-use reaction mastermix. From each cDNA, 3 replicates were assayed by $\mathrm{qPCR}$. The quantification cycle $\left(\mathbf{C}_{\mathbf{q}}\right)$ threshold was automatically determined by the thermocycler software and was manually adjusted for each target gene. For data analysis, the software qbasePLUS (Biogazelle NV, Zwijnaarde, Belgium) was used to perform inter-run calibration, to determine target-specific amplification efficiencies and to test for expression stability of reference genes. Reference genes $Y W H A Z$ and RPS 19 were recommended and used for normalization. After normalization, $\mathrm{C}_{\mathrm{q}}$ values were related to a calibrator produced from untreated tissues harvested at slaughter and results were calculated as relative expression.

\section{Western Blots}

The tissue samples were frozen in liquid nitrogen immediately after removing them from the Ussing chambers and stored at $-80^{\circ} \mathrm{C}$. For isolation of total protein, the samples were homogenized in lysis buffer $(10 \mathrm{mM}$ Tris, $140 \mathrm{~m} M \mathrm{NaCl}, 5 \mathrm{~m} M$ EDTA, $1 \%$ Triton $\mathrm{X}, 1$ $\mathrm{m} M$ phenylmethanesulfonyl fluoride, $1 \mathrm{~m} M$ dithiothreitol) supplemented with complete EDTA-free protease inhibitor cocktail (Roche Diagnostics, Mannheim, Germany). The protein concentration of the resulting solution was determined with the Pierce $660 \mathrm{~nm}$ protein assay (Thermo Scientific, Rockford, IL) on an EnSpire Multimode Plate Reader (Perkin Elmer). Total sample protein $(20 \mu \mathrm{g})$ and prestained protein-weight marker (5 $\mu \mathrm{L}$; Thermo Fisher Scientific) were electrophoretically separated in running buffer (192 $\mathrm{m} M$ L-glycine, $25 \mathrm{mM}$ Tris, $0.1 \%$ SDS, $\mathrm{pH} 8.3$ ) at a constant $150 \mathrm{~V}$ by SDSPAGE in a $10 \%$ polyacrylamide gel for $1 \mathrm{~h}$ and semidry transferred in transfer buffer $(48 \mathrm{~m} M$ L-glycine, 39 $\mathrm{m} M$ Tris, $0.037 \%$ SDS, $20 \%$ methanol, $\mathrm{pH}$ 9.2) at a 
constant $60 \mathrm{~mA}$ and $15 \mathrm{~V}$ onto polyvinylidene fluoride membrane for $45 \mathrm{~min}$. Afterward the membrane was blocked in 5\% milk powder (Carl Roth, Karlsruhe, Germany) diluted in Tris-buffered saline (50 $\mathrm{m} M$ Tris, 150 $\mathrm{m} M \mathrm{NaCl}$ ) containing $0.1 \%$ Tween (TBST) at room temperature for $2 \mathrm{~h}$. The membrane was then shortly washed in TBST and incubated overnight at $4^{\circ} \mathrm{C}$ with the primary antibody, which was diluted in TBST containing $2.5 \%$ milk powder and $0.1 \%$ sodium azide $\left(\mathrm{NaN}_{3}\right)$. The following primary antibodies were used for Western blotting: monoclonal mouse anti-claudin- 4 (1:500, Invitrogen, Carlsbad, CA), monoclonal mouse anti-occludin, polyclonal rabbit anti-claudin-1, and polyclonal rabbit anti-claudin-7 (1:1,000, Invitrogen). A mouse anti-GAPDH antibody (Invitrogen) was used for normalization. After incubation, the membrane was washed in TBST several times and incubated for $45 \mathrm{~min}$ in a solution of TBST containing $2.5 \%$ milk powder and the horseradish peroxidase-linked secondary antibodies goat anti-mouse $(1: 1,000)$ and goat anti-rabbit $(1: 2,500$; Cell Signaling Technology, Danvers, MA). After further washes in TBST, the protein signals were visualized via an enzymatic reaction by chemiluminescence imaging (SuperSignal West Dura Extended Duration Substrate, Thermo Fisher Scientific) and images obtained by ChemiDoc MP System (BioRad Laboratories). Signal quantification was performed using the ImageLab Software of the ChemiDoc MP System.

\section{Immunostaining for TJ Proteins}

Immunostaining was performed as previously described (Stumpff et al., 2011). Tissue samples were fixed in $4 \%$ paraformaldehyde for $1 \mathrm{~h}$, followed by an incubation step with $25 \mathrm{mM}$ L-glycine for $5 \mathrm{~min}$ and a subsequent treatment with ascending concentrations of sucrose, namely 10, 20, and $30 \%$ for at least $1 \mathrm{~h}$. Tissue samples were then frozen in methylbutane, which was cooled down by liquid nitrogen, placed in a cryostat, and coated with Tissue-Tek OCT compound (Sakura Finetek, Alphen aan den Rijn, the Netherlands). Afterward, samples were cut into $5-\mu \mathrm{m}$ slices, mounted onto glass slides and cooked in a $1 \mathrm{~m} M$ EDTA solution ( $\mathrm{pH}$ 8.0) for 10 min for antigen retrieval. The tissue samples were permeabilized in $0.5 \%$ Triton-X100 and blocked in $6 \%$ goat serum for 60 min. Afterward, tissue samples were stained with polyclonal rabbit anti-claudin-1 and monoclonal mouse anti-claudin-4 antibodies (Invitrogen) or monoclonal mouse anti-occludin (Invitrogen) and polyclonal rabbit anti-claudin-7 antibodies (Abcam, Cambridge, UK) in a dilution of 1:250. The secondary antibodies were Alexa Fluor $594 \mathrm{~nm}$ goat anti-mouse IgG and Cy5 goat anti-rabbit IgG (Cell Signaling Technology, Danvers, MA), used at dilutions of 1:500. Cell nuclei were stained using 4',6-diamidino-2-phenylindole dihydrochloride at a dilution of 1:1,000. Images were obtained using a confocal laser scanning microscope (Zeiss LSM 510, Carl Zeiss, Jena, Germany).

\section{Statistical Analysis}

The $P$-values were calculated by using the statistical software SigmaPlot 11 (Systat Software Inc., San José, $\mathrm{CA}$ ). Western blot and qPCR data were compared by 1-way ANOVA. Electrophysiological data were arithmetically pooled over 1 -h periods (equivalent to fluo-

Table 1. Sequences of primers and probes used for quantitative reverse-transcription PCR

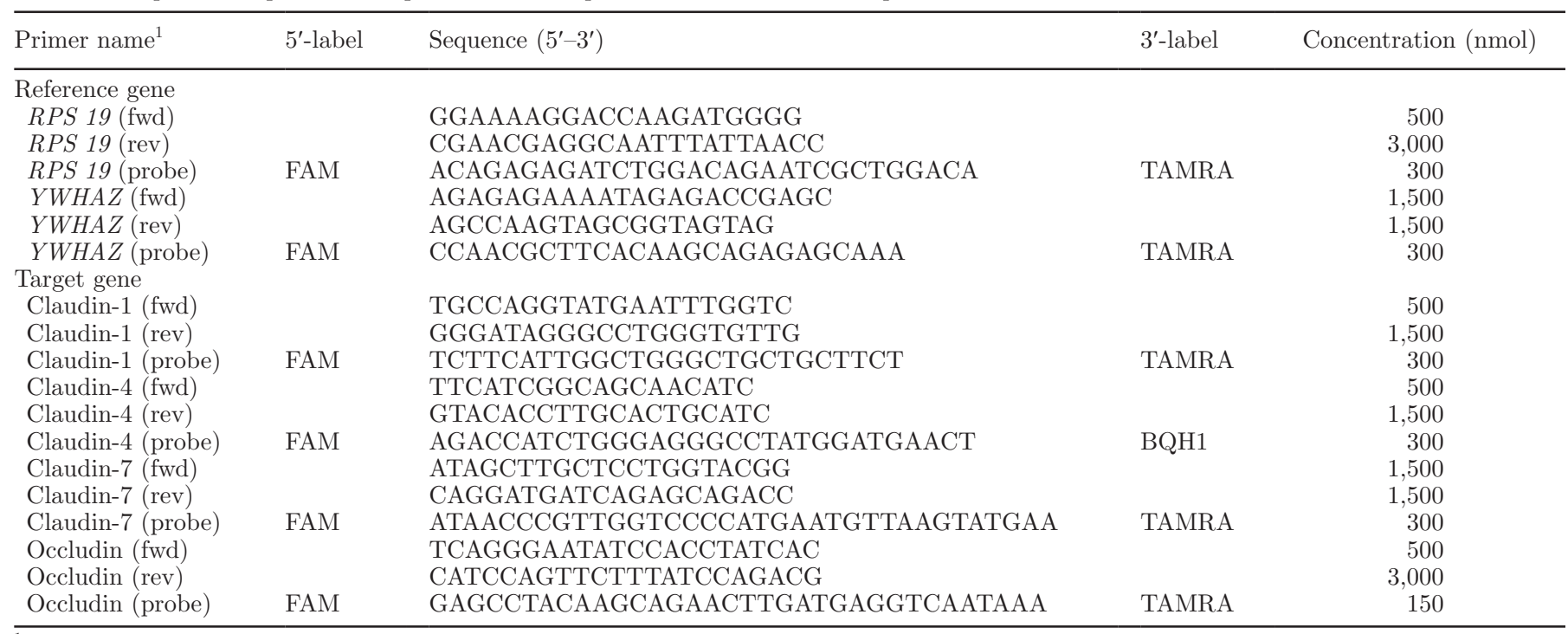

${ }^{1}$ Fwd = forward; rev = reverse; FAM = 6-carboxy-fluorescein; TAMRA = 6-carboxy-tetramethylrhodamine; BHQ = blackhole quencher. 
rescein flux periods) and tested by the Student's paired $t$-test versus the preincubation value. Fluorescein flux rates from the third to the seventh period were tested by 2 -way ANOVA for the factors flux period, mucosal incubation conditions $[\mathrm{pH}$ 6.1, $\mathrm{pH} 5.1$, and group $\mathrm{pH}$ 5.1 (SCFA challenge)], and their 2-way interactions. Because the factor flux period $(P=0.87)$ and the interaction of mucosal incubation conditions $\times$ flux period $(P=0.99)$ were not significant, only the LSM for the factor mucosal incubation conditions are presented. All other data are presented as means \pm standard error of the mean.

\section{RESULTS}

\section{Tissue Conductance and Short-Circuit Current}

Figure 1 shows $G_{\mathrm{t}}$ and $I_{\mathrm{sc}}$ data from epithelia incubated at either mucosal $\mathrm{pH} 6.1$ or 5.1 over $7 \mathrm{~h}$, and from epithelia incubated with $100 \mathrm{~m} M$ SCFA at $\mathrm{pH} 5.1$ for 2 $\mathrm{h}$, followed by incubation with SCFA-free buffer at $\mathrm{pH}$ 6.1 for another $5 \mathrm{~h}$. All 3 groups started with a similar $G_{\mathrm{t}}\left(\sim 2.4 \mathrm{mS} / \mathrm{cm}^{2}\right)$. The $G_{\mathrm{t}}$ of tissues incubated at $\mathrm{pH}$ 6.1 and 5.1 remained at a low level with only numerical increase at pH 5.1 after $7 \mathrm{~h}$. However, an incubation at $\mathrm{pH} 5.1$ in combination with SCFA increased $G_{\mathrm{t}}$ after $2 \mathrm{~h}$ (to $6.42 \pm 1 \mathrm{mS} / \mathrm{cm}^{2} ; P<0.05$ ). Moreover, the switch of the SCFA and acid-challenged epithelia to control buffer at $\mathrm{pH} 6.1$ was not linked to recovery but to further elevation of $G_{\mathrm{t}}(P<0.05)$ in the following flux periods, reaching a peak value of $12.61 \pm 2.25 \mathrm{mS}$ / $\mathrm{cm}^{2}$ at $6 \mathrm{~h}$ (Figure $\left.1 \mathrm{~A}\right)$.

The $I_{\mathrm{sc}}$ rapidly decreased after mucosal addition of the SCFA-containing solution at $\mathrm{pH}$ 5.1. It changed from a pre-incubation value of $1.46 \pm 0.17 \mu \mathrm{Eq} /\left(\mathrm{cm}^{2} \cdot \mathrm{h}\right)$ to $0.28 \pm 0.28 \mu \mathrm{Eq} /\left(\mathrm{cm}^{2} \cdot \mathrm{h}\right)$ in the second flux period $(P<0.05)$, the latter value being not significantly different from zero. Importantly, $I_{\mathrm{sc}}$ of epithelia in group pH 5.1 (SCFA challenge) slowly increased back to 1.02 $\pm 0.61 \mu \mathrm{Eq} /\left(\mathrm{cm}^{2} \cdot \mathrm{h}\right)$ after returning to control buffer solution with $\mathrm{pH}$ 6.1, indicating that epithelia were still viable and performing active ion transport despite the continuous increase in $G_{\mathrm{t}}$. The time course of $I_{\mathrm{sc}}$ did not differ between groups $\mathrm{pH} 6.1$ and $\mathrm{pH} 5.1$.

\section{Fluorescein Flux Rates}

Fluorescein is a 330 Da and negatively charged molecule. In many epithelia its transepithelial flux is attributed to the paracellular permeation pathway. At $\mathrm{pH}$ 6.1, $J_{\text {ms-fluor }}$ remained low during the course of the experiment $\left[0.37 \pm 1.94 \mathrm{nmol} /\left(\mathrm{cm}^{2} \cdot \mathrm{h}\right)\right]$, whereas incubation at a $\mathrm{pH}$ at 5.1 induced a trend but not yet significant increase of $J_{\text {ms-fluor }}$ in flux periods 3 to 7 [3.20 $\pm 1.59 \mathrm{nmol} /\left(\mathrm{cm}^{2} \cdot \mathrm{h}\right) ;$ Figure 2]. In the group $\mathrm{pH} 5.1$

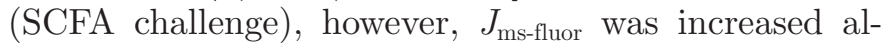
most 40-fold compared with control tissues of group $\mathrm{pH}$ 6.1 throughout flux periods 3 to $7[13.96 \pm 1.46 \mathrm{nmol} /$ $\left(\mathrm{cm}^{2} \cdot \mathrm{h}\right), P<0.05 ;$ Figure 2].

\section{Expression of TJ Proteins}

To identify the structural basis of the observed changes in $G_{\mathrm{t}}$ and $J_{\mathrm{ms}-\text { fluor }}$, the expression of TJ proteins
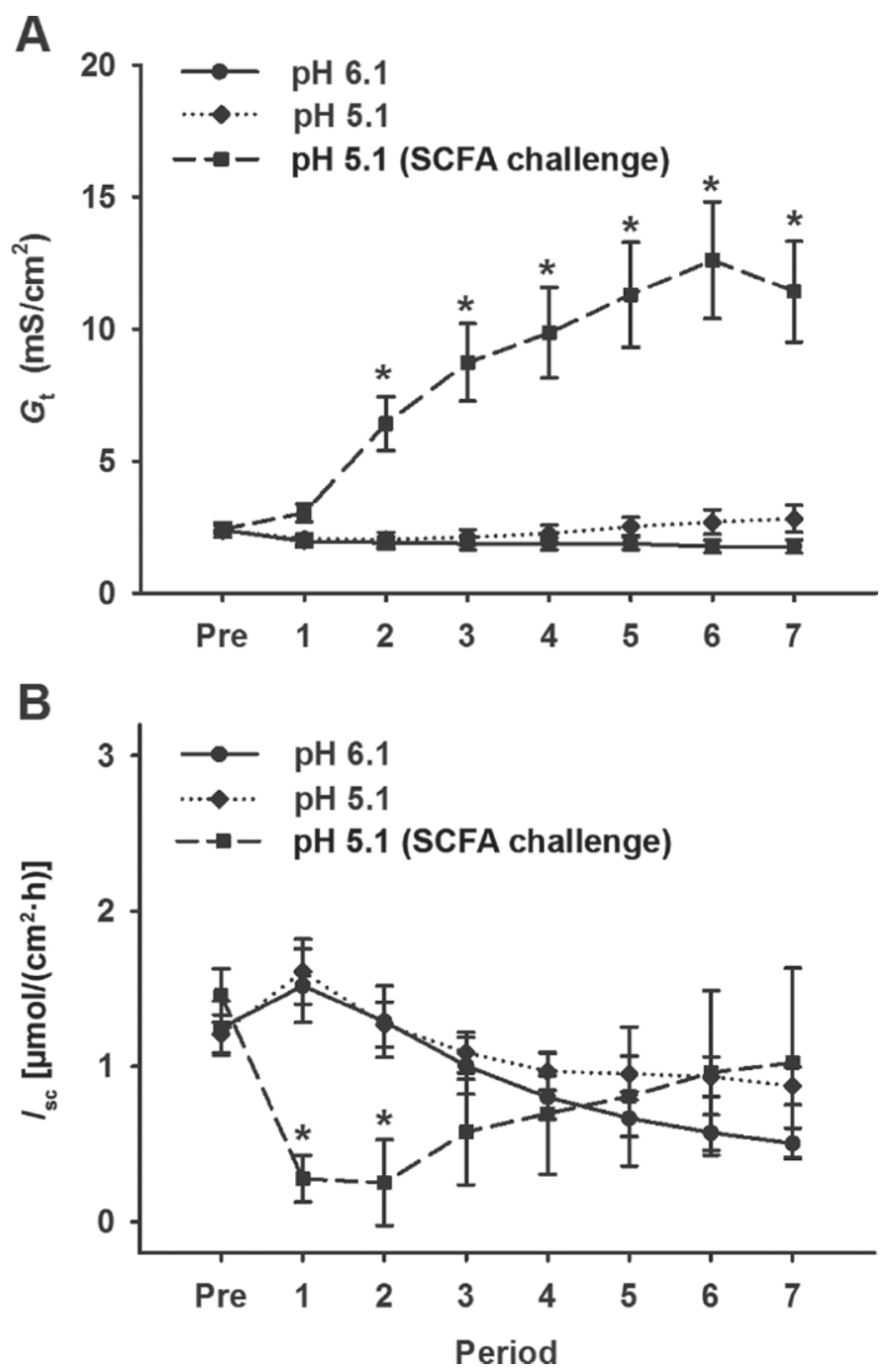

Figure 1. Influence of low mucosal $\mathrm{pH}$ with or without short-chain fatty acids (SCFA) on tissue conductance $\left(G_{\mathrm{t}}\right)$ and short-circuit current $\left(I_{\mathrm{sc}}\right)$. Ussing chamber experiments with ruminal tissues were performed under 3 different $\mathrm{pH}$ conditions: incubation at mucosal $\mathrm{pH} 6.1$ or 5.1 in the absence of SCFA for $7 \mathrm{~h}$ or mucosal pH 5.1 with $100 \mathrm{mM}$ SCFA ( $60 \mathrm{~m} M$ acetate, $30 \mathrm{~m} M$ propionate, and $10 \mathrm{~m} M$ butyrate) for the first $2 \mathrm{~h}$, followed by mucosal $\mathrm{pH} 6.1$ without SCFA for the remaining $5 \mathrm{~h}$. Values for $G_{\mathrm{t}}(\mathrm{A})$ and $I_{\mathrm{sc}}(\mathrm{B})$ were recorded each minute and arithmetically pooled over $1 \mathrm{~h}$. Pooled values are presented as mean values \pm SEM. ${ }^{*} P<0.05$ compared with the preincubation (Pre) value. $\mathrm{n}=8$ to 12 . 
was analyzed by qPCR and Western blotting. Figure 3 shows the analysis of the mRNA expression. Compared with mRNA that was isolated from untreated tissues harvested immediately after slaughter (i.e., without incubation in Ussing chambers), there were only minor (claudin-1) or no influences of the 7-h Ussing chamber incubation at $\mathrm{pH} 6.1$ or 5.1 on the mRNA expression of the tested TJ proteins. The same applied to occludin, claudin-1, and claudin-4 in the group pH 5.1 (SCFA challenge). By contrast, mRNA expression of claudin-7 was selectively decreased by $>80 \%$ in group $\mathrm{pH} 5.1$ (SCFA challenge; Figure 3).

On the protein level, claudin-7 was numerically and claudin-4 significantly decreased $(P<0.05)$ in group $\mathrm{pH}$ 5.1 compared with the control group $\mathrm{pH}$ 6.1. In group pH 5.1 (SCFA challenge), however, occludin, claudin-4, and claudin-7 (i.e., 3 out of 4 tested TJ proteins) were decreased by $>70 \%(P<0.05$; Figure 4$)$.

Taken together, mucosal pH 5.1 in combination with SCFA initiated a short-term nonreversible, transcriptional decrease of claudin-7 expression and a posttranscriptional decrease of claudin- 4 and occludin expression, whereas a $\mathrm{pH}$ of 5.1 in the absence of SCFA induced only posttranscriptional decrease in claudin-4 protein expression.

\section{Distribution of TJ Proteins Under Different pH Conditions}

To investigate whether the decrease of different TJ proteins results also in a change in $\mathrm{TJ}$ protein abundance in the TJ domain of ruminal epithelial cells, epithelial distribution of TJ proteins was investigated by confocal laser scanning microscopy on immunostained ruminal tissue samples. Under control conditions in group $\mathrm{pH}$ 6.1 , TJ proteins formed a network through the whole ruminal epithelia (Figure 5). Within this network, claudin-1, and occludin could be localized through all cell layers below the uppermost stratum corneum, whereas claudin- 4 appeared to be more restricted to the stratum granulosum. By contrast, accumulations of claudin-7 were exclusively detected in cells of the stratum corneum (Figure 5B). The permeation marker fluorescein that had been applied from the luminal side in Ussing chambers was more or less restricted to cells of the stratum corneum, delineating a sharp border toward the stratum granulosum.

In group $\mathrm{pH}$ 5.1, claudin-1 showed a slightly reduced intensity but was still present as a TJ network in all noncornified cell layers [i.e., stratum basale, stratum spinosum, and stratum granulosum (Figure 5A)]. A reduced staining intensity was also observed for claudin-4 (Figure 5A) and occludin (Figure 5B), but these

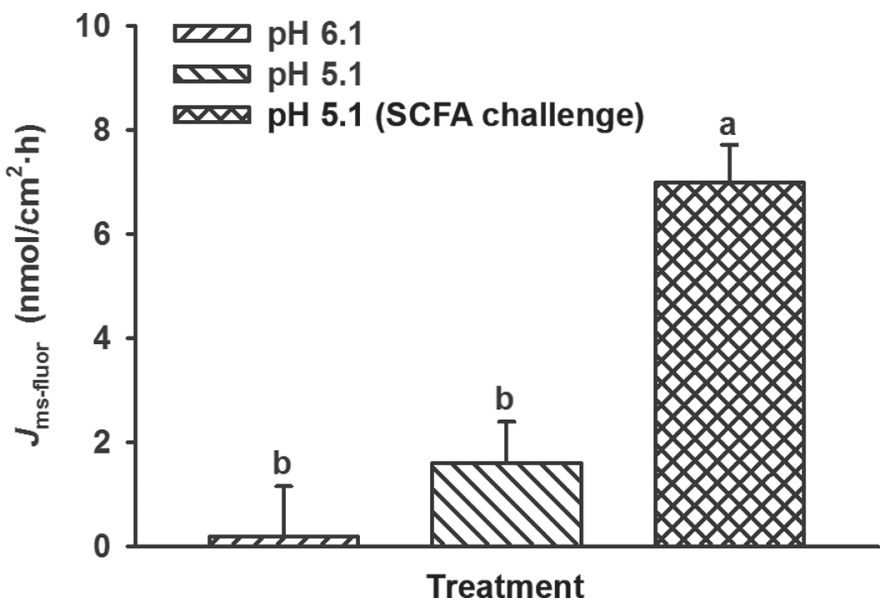

Figure 2. Influence of low mucosal $\mathrm{pH}$ with or without short-chain fatty acids (SCFA) on fluorescein flux rates. Fluorescein flux rates from the mucosal to the serosal side $\left(J_{\text {ms-fluor }}\right)$ are presented for ruminal tissues incubated at mucosal $\mathrm{pH} 6.1$ or 5.1 in the absence of SCFA for $7 \mathrm{~h}$ or mucosal $\mathrm{pH} 5.1$ with $100 \mathrm{~m} M$ SCFA for the first $2 \mathrm{~h}$, followed by mucosal $\mathrm{pH} 6.1$ without SCFA for the remaining $5 \mathrm{~h}$. Fluorescein flux rates in periods 3 through 7 did not differ for the factor flux period $(P$ $=0.87)$ and the interaction of mucosal incubation conditions $\times$ flux period $(P=0.99)$. Therefore, LSM + SEM are presented only for the factor mucosal incubation conditions (pooled per epithelium over flux periods 3 to 7; equals third to seventh hour of incubation). Columns that do not share a common letter ( $\mathrm{a}$ or b) are significantly different. ${ }_{\mathrm{a}, \mathrm{b}} \mathrm{P}<0.01 ; \mathrm{n}=8$ to 12 .

2 proteins additionally showed partial localization out of the TJ network. In contrast, claudin-7 was no longer in evidence in the stratum corneum or elsewhere in the epithelium (Figure 5B). Fluorescein, which had been restricted to the stratum corneum under control conditions in group $\mathrm{pH}$ 6.1, was also detected with lower intensity in and around cells below the stratum corneum in group pH 5.1 (Figure 5B).

The most obvious changes in TJ protein distribution could be observed in ruminal tissues of group $\mathrm{pH} 5.1$ (SCFA challenge). Whereas claudin-1 was still detectable in small amounts in the subcellular TJ, claudin-4, claudin-7, and occludin were almost absent throughout all cell layers and could no longer be visualized as components of TJ. Simultaneously, our study showed the distribution of fluorescein through the whole tissue without any indication of a barrier between the different cell layers (Figures 5A and 5B). Another prominent feature was that many epithelia of group pH 5.1 (SCFA challenge) showed overt swelling of cells in the stratum corneum, forming a multi-layer of balloon cells (Figure $5 \mathrm{~A})$.

\section{DISCUSSION}

It is well known that high-grain feeding can adversely affect the barrier function of the ruminal epithelium 

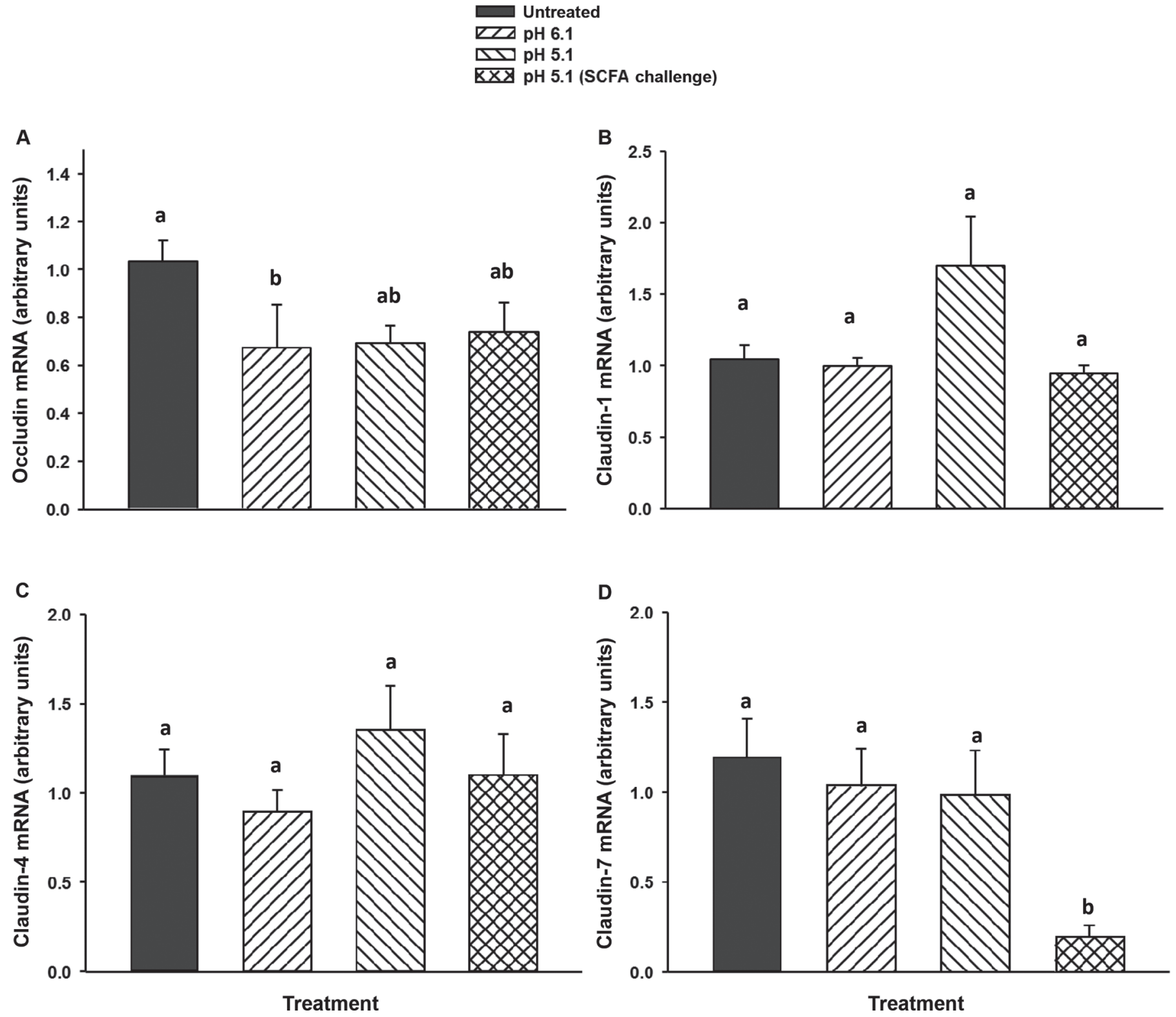

Figure 3. Influence of low mucosal $\mathrm{pH}$ with or without short-chain fatty acids (SCFA) on mRNA expression of tight junction (TJ) proteins. Ruminal tissues were incubated at mucosal $\mathrm{pH} 6.1$ or 5.1 in the absence of SCFA for $7 \mathrm{~h}$ or mucosal $\mathrm{pH} 5.1 \mathrm{with} 100 \mathrm{~m} M$ SCFA for the first $2 \mathrm{~h}$, followed by mucosal $\mathrm{pH} 6.1$ without SCFA for the remaining $5 \mathrm{~h}$. Changes in mRNA expression of claudin-1, claudin-4, claudin-7, and occludin were evaluated by quantitative real-time PCR. Untreated samples were stored directly after slaughtering, and all other samples were stored after incubation for $7 \mathrm{~h}$ in the Ussing chamber. Expression data were normalized to $Y W H A Z$ and $R P S 19$ and calibrated to untreated tissues harvested at slaughter. Values are means + SEM. Columns that do not share a common letter (a or b) are significantly different. ${ }^{\mathrm{a} b} P<$ $0.05 ; \mathrm{n}=10$ to 12 .

(Zebeli et al., 2012; Klevenhusen et al., 2013). To prevent such adverse effects, the rumen adapts to the changing dietary conditions, mainly as a result of the change in luminal production rates of SCFA (Penner et al., 2011). The accumulation and dissociation of SCFA in ruminal fluid decreases $\mathrm{pH}$ (Sutton et al., 2003; Penner et al., 2007, 2009) and may lead to the onset of ruminal acidosis (Owens et al., 1998; Plaizier et al., 2008). Summarized scientific data suggest that health disturbances due to SARA depend on both the severity and the duration of $\mathrm{pH}$ decrease. In general, feeding regimens that decrease ruminal $\mathrm{pH}$ to $<5.8$ for $>5$ to $6 \mathrm{~h} / \mathrm{d}$ (Zebeli et al., 2012) or to $<5.6$ for $>3 \mathrm{~h} / \mathrm{d}$ (Gozho et al., 2005) have a very high probability of be- 
A

\begin{tabular}{|c|c|c|c|c|}
\hline & $\begin{array}{l}\mathrm{pH} \\
6.1\end{array}$ & $\begin{array}{l}\mathrm{pH} \\
5.1\end{array}$ & $\begin{array}{l}\text { pH } 5.1 \\
\text { challer }\end{array}$ & $\begin{array}{l}\text { SCFA } \\
\text { ge) }\end{array}$ \\
\hline occludin & entrives & insint & & $56 \mathrm{kDa}$ \\
\hline claudin-1 & & $=$ & $=$ & $22 \mathrm{kDa}$ \\
\hline claudin-4 & $\mathbf{m}$ & $=$ & axcosent & $22 \mathrm{kDa}$ \\
\hline claudin-7 & $\longrightarrow$ & $=$ & & $22 \mathrm{kDa}$ \\
\hline APDH & $=$ & $=$ & 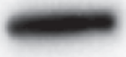 & $36 \mathrm{kDa}$ \\
\hline
\end{tabular}

$\square 7 \mathrm{pH} 6.1$

ख 5.1 (SCFA challenge)

B
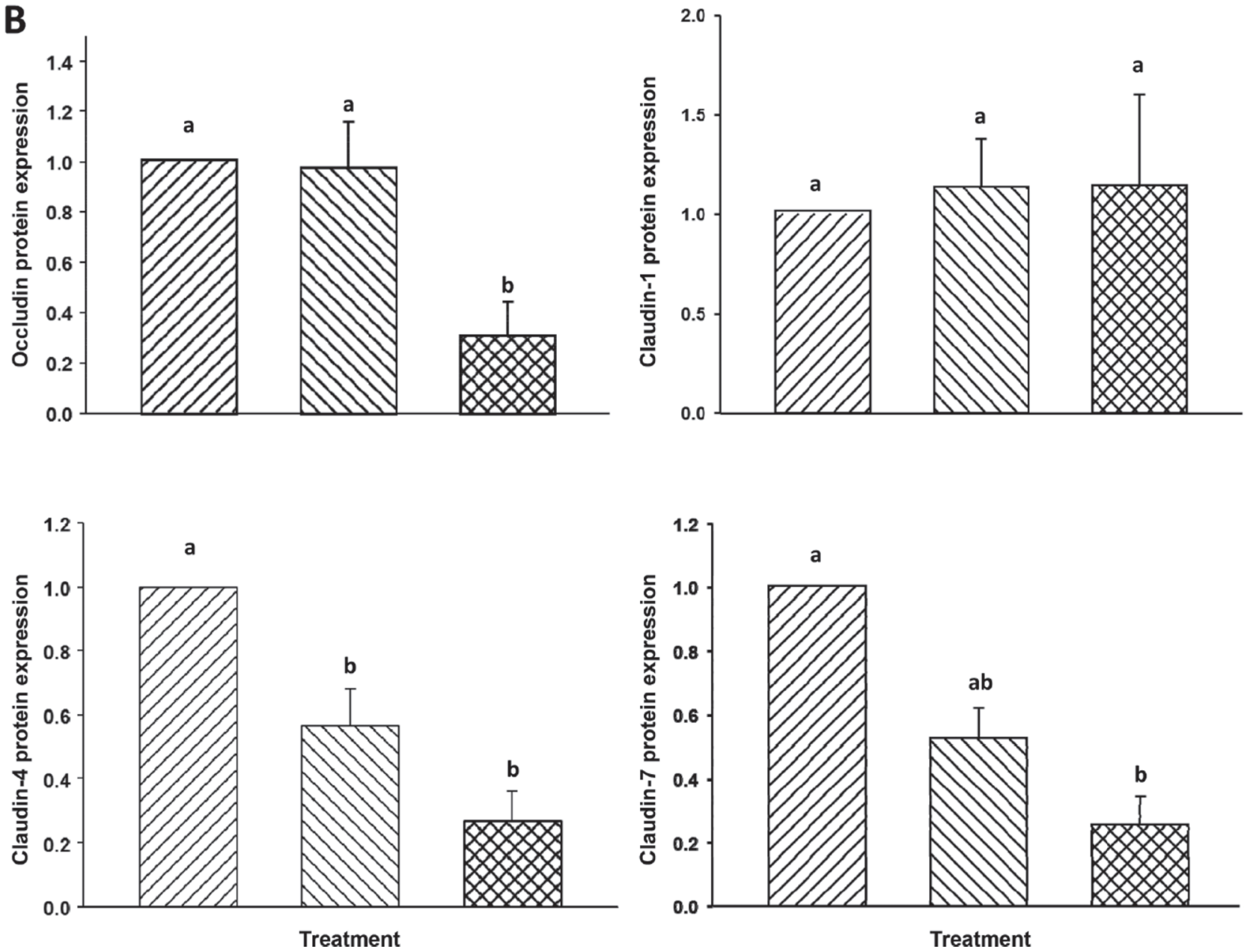

Figure 4. Influence of low mucosal $\mathrm{pH}$ with or without short-chain fatty acids (SCFA) on tight junction (TJ) protein expression. Ruminal tissues were incubated at mucosal $\mathrm{pH} 6.1$ or 5.1 in the absence of SCFA for $7 \mathrm{~h}$ or mucosal $\mathrm{pH} 5.1$ with $100 \mathrm{~m} M$ SCFA for the first $2 \mathrm{~h}$, followed by mucosal pH 6.1 without SCFA for the remaining $5 \mathrm{~h}$. Changes in protein expression of claudin-1, claudin-4, claudin-7, and occludin were evaluated by Western blot analysis. Representative blots are shown in panel A. Graphs in panel B show TJ protein expression normalized for GAPDH as mean values + SEM. Columns that do not share a common letter ( $\mathrm{a}$ or $\mathrm{b}$ ) are significantly different. ${ }^{\mathrm{a}, \mathrm{b}} P<0.05 ; \mathrm{n}=10$ to 12 . 
A

pH 6.1
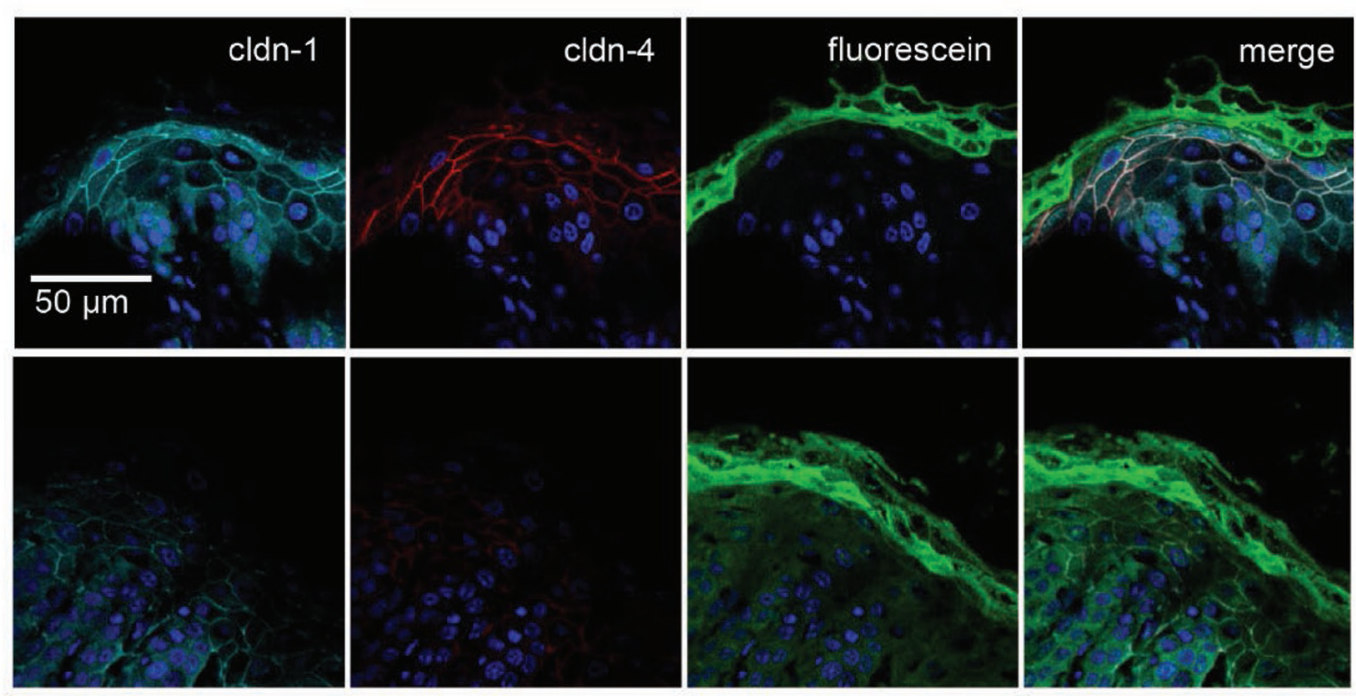

pH 5.1
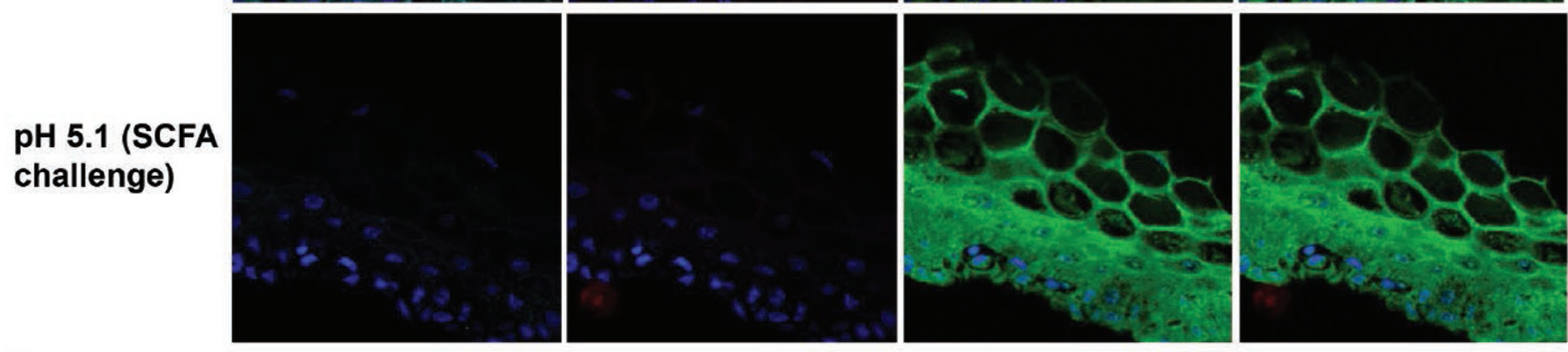

B

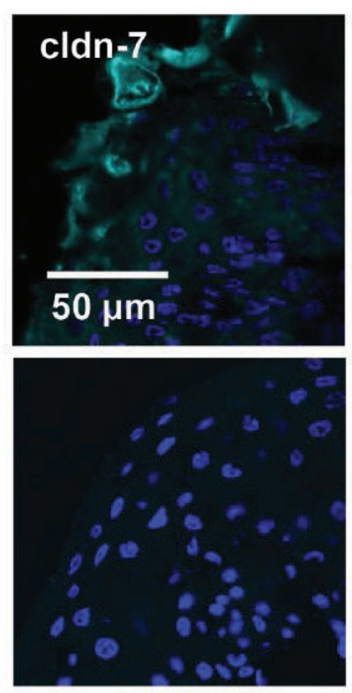

\section{occl}

pH 6.1

pH 5.1
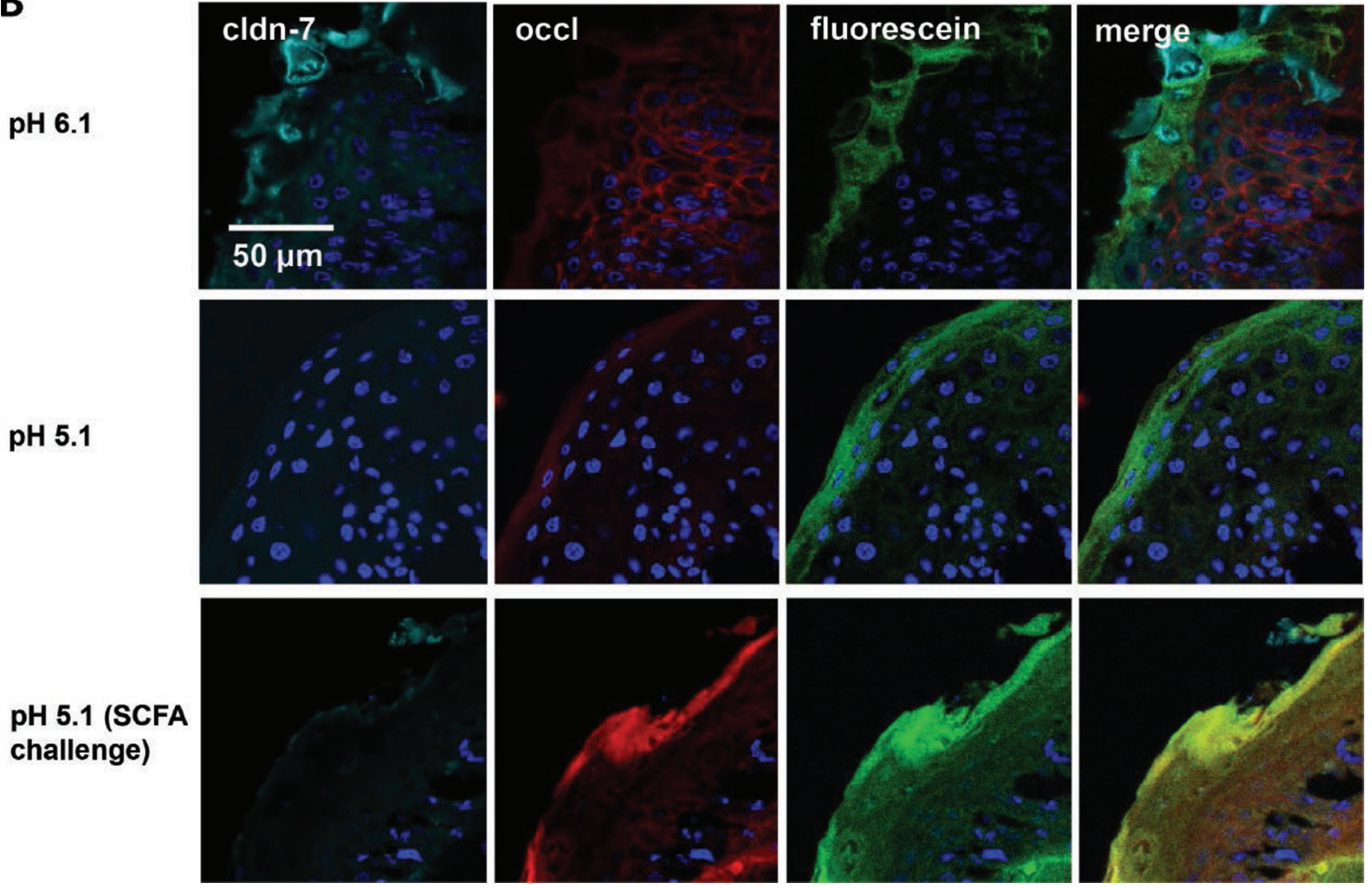

Figure 5. Influence of low mucosal $\mathrm{pH}$ with or without short-chain fatty acids (SCFA) on tight junction (TJ) localization. Localization of the TJ proteins (A) claudin (cldn)-1 (cyan)/cldn-4 (red) and (B) occludin (occl) (red)/cldn-7 (cyan) in ruminal epithelia under defined pH conditions: incubation at mucosal pH 6.1 or 5.1 in the absence of SCFA for $7 \mathrm{~h}$ or mucosal $\mathrm{pH} 5.1$ with $100 \mathrm{~m} M$ SCFA for the first $2 \mathrm{~h}$, followed by mucosal pH 6.1 without SCFA for the remaining $5 \mathrm{~h}$. Fluorescein is represented in green, and cell nuclei are represented in blue. 
ing associated with health disturbances. Key events in the chain of pathophysiological processes are morphological and histological alterations of ruminal papillae that suggest an impaired barrier function of ruminal epithelia. (Steele et al., 2009, 2011). More specifically, Liu et al. (2013) showed that a decrease of intraruminal $\mathrm{pH}$ to 5.3 (measured at slaughter 4 to $5 \mathrm{~h}$ after the last feeding) was linked to damages in TJ barrier function in high-grain-fed goats (65\% grain) after 7 wk. On the other hand, Penner et al. (2010) demonstrated that a single short and mild episode of SARA with $\mathrm{pH}<5.8$ for only $2 \mathrm{~h}$ (nadir $\mathrm{pH} 5.48$ ) does not induce barrier dysfunction and proposed that additional or repeated insults are needed to trigger barrier failure in ruminal epithelia. The present study hypothesized that high concentrations of permeable organic acids is one of the main factors that determine the efficacy by which low $\mathrm{pH}$ induces barrier failure. The present study was designed to prove this hypothesis. Unlike the situation in vivo, the current Ussing chamber model ex vivo allows controlled variation of mucosal $\mathrm{pH}$ and SCFA concentration. Furthermore, it does not require experimental acidosis induction in vivo, which may reach a severity that justifies animal welfare concerns.

Whereas one of our previous studies had already demonstrated that a low $\mathrm{pH}$ of 5.2 , has only moderate effects on the ruminal epithelial barrier (Penner et al., 2010), the present study clearly demonstrated, for the first time, that it requires the concurrent presence of high SCFA concentrations to trigger a profound impairment of epithelial barrier function. Barrier failure was demonstrated by an increased passive conductivity to ions $\left(\boldsymbol{G}_{\mathrm{t}}\right)$, which developed rapidly and continued even after epithelia had been returned to physiological luminal $\mathrm{pH}$ of 6.1. These findings conform to another study that showed a fast increase of $G_{\mathrm{t}}$ in ruminal tissues after decreasing the mucosal $\mathrm{pH}$ from 7.4 to 5.5 (Gaebel et al., 1989). In contrast to our study, Gaebel et al. (1989) always used incubation solutions containing SCFA so that they could ascribe their effects on sodium and chloride movement across the epithelium primarily to low $\mathrm{pH}$, not separating possible effects of SCFA. Gaebel et al. (1989) interpreted their findings by predominant effects on transport mechanisms because an involvement of TJ proteins in barrier formation of the ruminal epithelium was disputed at that time and only later confirmed in 2005 (Graham and Simmons, 2005).

A low $\mathrm{pH}$ of 5.1 in the co-presence of $100 \mathrm{~m} M$ SCFA clearly elicits alterations of transport mechanisms as evidenced by the rapid decrease of $I_{\mathrm{sc}}$ in the present study. The $I_{\mathrm{sc}}$ represents the net charge transfer across the epithelium and its physiologically positive value indicates superiority of active net cation absorption (primarily $\mathrm{Na}^{+}$) over net anion absorption (primarily $\mathrm{SCFA}^{-}$and $\mathrm{Cl}^{-}$; Leonhard-Marek et al., 2010). The finding of decreasing $I_{\mathrm{sc}}$ upon exposure to low $\mathrm{pH}$ and SCFA could point to increased anion currents across the ruminal epithelium carried by $\mathrm{SCFA}^{-}$absorption via an $\mathrm{SCFA}^{-}$conductance (Stumpff et al., 2009; Georgi et al., 2014). An alternative explanation would be that active transport processes are largely compromised by the SCFA-fortified acidification of intracellular $\mathrm{pH}$, primarily based on compromised $\mathrm{Na}^{+} / \mathrm{K}^{+}$ATPase function (Gaebel et al., 1989). Proceeding from the latter option, it is important to acknowledge that changes of $I_{\mathrm{sc}}$ were reversible by returning to mucosal $\mathrm{pH} 6.1$ in the present study. This recovery of active ion transport after the acidic insult evidences that the epithelium was damaged but still viable, thereby supporting the appropriateness of the model used and the applicability of the conclusions drawn from it.

Whereas the reversible decrease of $I_{\mathrm{sc}}$ in our study proved the viability of ruminal epithelia, the nonreversible increase of $G_{\mathrm{t}}$ indicated a sustained disturbance of barrier function persisting after the acidotic result had been removed. This conclusion is further supported by the finding that fluorescein flux rates were increased by a low $\mathrm{pH}$ in combination with SCFA, whereas low $\mathrm{pH}$ alone showed only a trend for an increase. Furthermore, we could demonstrate intense penetration of fluorescein into the deeper layers of the ruminal tissue by laser scanning microscopy. The latter holds true even more when considering that large amounts of fluorescein may have been washed out during tissue processing. The abrupt disappearance of fluorescein staining below the stratum corneum seen at $\mathrm{pH} 6.1$ justifies the postulate of a tight permeation barrier formed by TJ proteins in subjacent epithelial layers, especially the stratum granulosum. Already the continuous application of mucosal pH 5.1 without SCFA allowed small amounts of fluorescein to penetrate that barrier into the underlying cell layers. When $\mathrm{pH} 5.1$ was combined with high SCFA concentrations, high amounts of fluorescein could be demonstrated in the whole tissue without any clear barrier delineation. These data confirm the hypothesis that TJ proteins are essential for epithelial barrier function in the ruminal epithelium and suggest a disturbed barrier function mediated by an altered TJ expression in our experiments.

The first systematic study on the key role of TJ proteins in ruminal barrier function was provided by Stumpff et al. (2011). They cultivated primary ruminal cells on filters and elucidated respectable paracellular resistance $\left(R^{\mathrm{p}}>720 \Omega \mathrm{cm}^{2}\right)$, which they attributed to the sealing properties of claudin-1 and claudin-4 (Van 
Itallie and Anderson, 2006; Stumpff et al., 2011). Our expression analysis extends these findings and shows that a low $\mathrm{pH}$ in combination with SCFA decreased the mRNA expression of claudin-7, as well as the protein expression of claudin- 4 , claudin-7, and occludin, which directly relates to increased $G_{\mathrm{t}}$ and increased $J_{\text {ms-fluor }}$. In contrast, a low $\mathrm{pH}$ alone showed only a partial reduction of claudin-4 protein expression, which seemed not to influence the $G_{\mathrm{t}}$ albeit it tended to increase $J_{\text {ms-fluor }}$ and the localization of fluorescein below the stratum corneum. Additionally, we demonstrated a redistribution of TJ proteins out of the TJ in the lower layers of the epithelium that was almost complete when SCFA and low $\mathrm{pH}$ were applied together. Occludin disappeared out of the TJ already at $\mathrm{pH} 5.1$ in the absence of SCFA, which was not linked to a significant change of $G_{\mathrm{t}}$. This may suggest a minor relevance of occludin retraction for $G_{\mathrm{t}}$ in this "mild" acidotic insult, which fits to the generally poorly established role of occludin for barrier formation. Albeit artificial overexpression of occludin in MDCK cell cultures increased the transepithelial resistance (McCarthy et al., 1996), a complete loss of occludin in knockout mice showed no changes in TJ structure and barrier function in the intestine (Saitou et al., 2000). As such, the functional role of occludin still awaits further clarification in ruminal epithelia, too. Claudin-1 and claudin-4 mainly disappeared out of the TJ at a low $\mathrm{pH}$ in combination with SCFA, which caused an increase of $G_{\mathrm{t}}$. This finding is not surprising considering that the sealing properties in ruminal epithelia are mainly attributed to claudin-1 and claudin-4 as previously discussed (Stumpff et al., 2011). Together, these findings complement findings from studies in vivo where longer periods of high-grain feeding downregulated the mRNA and protein expression of claudin-4 and occludin simultaneously, and induced a redistribution of claudin- 1 , claudin- 4 , and occludin out of the TJ (Liu et al., 2013).

While claudin- 1 and claudin- 4 fulfil obvious barrierforming roles in the nonkeratinized strata of the ruminal epithelium, the role of claudin-7 and its transcriptional decrease in our SARA model is not very easily interpreted as claudin-7 resides primarily in the stratum corneum. A link to such interpretation may be provided by parallels to psoriasis of the human skin. Skin and rumen are both stratified keratinized epithelia and show marked structural similarity. Tight junction proteins play major roles in barrier function of both skin and rumen epithelia (Kirschner et al., 2010; Stumpff et al., 2011; Kirschner and Brandner, 2012). Dermal psoriasis involves hyper- and parakeratosis as does SARA. For early-stage psoriasis and plaque-type psoriasis, Kirschner et al. (2009) demonstrated alterations of the
TJ structure mainly mediated by a downregulation of claudin- 1 and claudin- 7 in the basal and the uppermost layers of the skin. This may point to the fact that the final stage of differentiation (i.e., keratinization) may be dependent or linked to adequate claudin-7 expression. In contrast to the skin where claudin-7 was found in all cell layers (Brandner, 2009), claudin-7 is primarily located in the nonviable cells of the stratum corneum in the ruminal epithelium (Stumpff et al., 2011). An indication for the possible role of claudin-7 in those nonviable cells of the ruminal stratum corneum may come from the study of Ding et al. (2012) who demonstrated that a depletion of claudin- 7 in mice caused intercellular gaps and cell matrix loosening. From this, it is obvious that claudin-7 assumes an essential role for cell adhesion. Transferred to the ruminal epithelium, it seems possible that claudin-7 ensures the integrity of the stratum corneum and plays a prominent role to protect the strata underneath the cornified layer. Based on this assumption, we propose that the absence of claudin-7 at low $\mathrm{pH}$ disturbs this protective role of the stratum corneum, which makes the cell layers underneath more vulnerable to injury.

The mechanisms by which SCFA promote TJ injury at low $\mathrm{pH}$ could rely on their barrier-breaking properties (Martin, 1963; Hirst, 1989). This concept has previously been discussed as a cause of ulcer development in the nonglandular squamous parts of gastric mucosa in pigs (Argenzio and Eisemann, 1996) and horses (Andrews et al., 2006). In a low pH environment, SCFA will increasingly bind protons, which enhances their ability to cross biological membranes by lipid diffusion. Once in the cytosol, protons are released and acidify intracellular $\mathrm{pH}$. As such, SCFA may serve as shuttles that translocate large amounts of protons from an acidic cell exterior into the cell (weak acid carrier model; Gutknecht, 1987). Similarly, an enhanced exchange of extracellular SCFA anions for intracellular $\mathrm{HCO}_{3}^{-}$due to low luminal pH (Aschenbach et al., 2009) will also result in acidification of intracellular $\mathrm{pH}$. Intracellular acidification and the enhanced influx of SCFA at low $\mathrm{pH}$ additionally elicit osmotic effects (cell swelling) and may give rise to inflammation (Argenzio and Eisemann, 1996).

Inflammation is a well-known feature of SARA, occurring both locally in the ruminal epithelium (Liu et al., 2013) and systemically (Gozho et al., 2005). In high-grain-fed goats, Liu et al. (2013) suggested a relationship between the locally increased expression of inflammatory cytokines, tumor necrosis factor- $\alpha$ and IFN- $\gamma$, and altered expression of TJ proteins in ruminal epithelia. Such suggestion is supported by the proven role of cytokines in barrier dysfunction of other 
gastrointestinal tissues like Crohn's disease and ulcerative colitis. In the human gut, IL-13, tumor necrosis factor- $\alpha$, and IFN- $\gamma$ reduce barrier function through a change in TJ protein expression (Schulzke et al., 2009). A decreased expression of claudin- 5 and claudin- 8 was observed in Crohn's disease and an increased expression of claudin-2 was observed in ulcerative colitis (Heller et al., 2005; Zeissig et al., 2007). So far, claudin-2, claudin-5, and claudin- 8 could not be identified in the ruminal epithelium (Stumpff et al., 2011). Therefore, it remains to be finally clarified in further studies inasmuch cytokines are directly involved in altered TJ protein expression and disturbed TJ formation of the rumen.

It may further be considered that SCFA, per se, can also influence TJ protein expression. Generally, low amounts have been suggested to have beneficial effects, whereas high amounts have the ability to disturb barrier function in other tissues (Ohata et al., 2005; Miyoshi et al., 2008; Peng et al., 2009; Plöger et al., 2012).

\section{CONCLUSIONS}

Our study provided the first direct evidence that a disturbed TJ barrier of the ruminal epithelium during SARA is caused by the combined action of low $\mathrm{pH}$ and high SCFA concentration. The disturbance of barrier function involves downregulation of selected TJ proteins and partial or complete translocation of all tested TJ proteins out of the TJ. Downregulation appeared transcriptional for claudin-7 and posttranscriptional for claudin- 4 and occludin. The acknowledgment of interlinked effects of ruminal $\mathrm{pH}$ and SCFA concentration on the ruminal epithelial barrier leads to the conclusion that susceptibility to SARA not only depends on ruminal $\mathrm{pH}$, which is a result of $\mathrm{H}^{+}$release, $\mathrm{H}^{+}$buffering, and $\mathrm{H}^{+}$removal, but also crucially depends on ruminal SCFA concentration, which is a result of SCFA production and SCFA removal, the latter primarily by ruminal absorption. This supports our previous postulate that the capacity of the rumen to absorb SCFA from the ruminal content is the key defense mechanism against SARA (Penner et al., 2009). Our results may also provide a better understanding on how various components of dairy cow diets can modify the severity of SARA by taking into account not only their potential to release and buffer $\mathrm{H}^{+}$during fermentation but also considering their potential to affect ruminal SCFA concentration.

\section{ACKNOWLEDGMENTS}

We gratefully acknowledge the expert technical assistance of Katharina Söllig and Uwe Tietjen (Institute of Veterinary Physiology, Freie Universität Berlin). Studies were supported, in part, by a grant of the Federal Office for Agriculture and Food (Bundesinstitut für Landwirtschaft und Ernährung, BLE, Germany) to J. R. Aschenbach and an Elsa Neumann Stipend to G. Greco.

\section{REFERENCES}

Andrews, F. M., B. R. Buchanan, S. H. Smith, S. B. Elliott, and A. M. Saxton. 2006. In vitro effects of hydrochloric acid and various concentrations of acetic, propionic, butyric, or valeric acids on bioelectric properties of equine gastric squamous mucosa. Am. J. Vet. Res. 67:1873-1882. https://doi.org/10.2460/ajvr.67.11.1873.

Argenzio, R. A., and J. Eisemann. 1996. Mechanisms of acid injury in porcine gastroesophageal mucosa. Am. J. Vet. Res. 57:564-573.

Aschenbach, J. R., S. Bilk, G. Tadesse, F. Stumpff, and G. Gäbel. 2009. Bicarbonate-dependent and bicarbonate-independent mechanisms contribute to nondiffusive uptake of acetate in the ruminal epithelium of sheep. Am. J. Physiol. Gastrointest. Liver Physiol. 296:G1098-G1107. https://doi.org/10.1152/ajpgi.90442.2008.

Aschenbach, J. R., and G. Gäbel. 2000. Effect and absorption of histamine in sheep rumen: Significance of acidotic epithelial damage. J. Anim. Sci. 78:464-470.

Aschenbach, J. R., N. B. Kristensen, S. S. Donkin, H. M. Hammon, and G. B. Penner. 2010. Gluconeogenesis in dairy cows: The secret of making sweet milk from sour dough. IUBMB Life 62:869-877. https://doi.org/10.1002/iub.400.

Aschenbach, J. R., G. B. Penner, F. Stumpff, and G. Gäbel. 2011. Ruminant Nutrition Symposium: Role of fermentation acid absorption in the regulation of ruminal pH. J. Anim. Sci. 89:1092-1107. https://doi.org/10.2527/jas.2010-3301.

Balda, M. S., and K. Matter. 2003. Epithelial cell adhesion and the regulation of gene expression. Trends Cell Biol. 13:310-318.

Bergman, E. N. 1990. Energy contributions of volatile fatty acids from the gastrointestinal tract in various species. Physiol. Rev. 70:567-590.

Brandner, J. M. 2009. Tight junctions and tight junction proteins in mammalian epidermis. Eur. J. Pharm. Biopharm. 72:289-294. https://doi.org/10.1016/j.ejpb.2008.08.007.

Bugaut, M. 1987. Occurrence, absorption and metabolism of short chain fatty acids in the digestive tract of mammals. Comp. Biochem. Physiol. B 86:439-472.

Ding, L., Z. Lu, O. Foreman, R. Tatum, Q. Lu, R. Renegar, J. Cao, and Y. H. Chen. 2012. Inflammation and disruption of the mucosal architecture in claudin-7-deficient mice. Gastroenterology 142:305-315. https://doi.org/10.1053/j.gastro.2011.10.025.

Furuse, M., M. Hata, K. Furuse, Y. Yoshida, A. Haratake, Y. Sugitani, T. Noda, A. Kubo, and S. Tsukita. 2002. Claudin-based tight junctions are crucial for the mammalian epidermal barrier: A lesson from claudin-1-deficient mice. J. Cell Biol. 156:1099-1111.

Gaebel, G., M. Bell, and H. Martens. 1989. The effect of low mucosal $\mathrm{pH}$ on sodium and chloride movement across the isolated rumen mucosa of sheep. Q. J. Exp. Physiol. 74:35-44.

Georgi, M. I., J. Rosendahl, F. Ernst, D. Günzel, J. R. Aschenbach, H. Martens, and F. Stumpff. 2014. Epithelia of the ovine and bovine forestomach express basolateral maxi-anion channels permeable to the anions of short-chain fatty acids. Pflugers Arch. 466:1689 1712. https://doi.org/10.1007/s00424-013-1386-x.

Gozho, G. N., J. C. Plaizier, D. O. Krause, A. D. Kennedy, and K. M. Wittenberg. 2005. Subacute ruminal acidosis induces ruminal lipopolysaccharide endotoxin release and triggers an inflammatory response. J. Dairy Sci. 88:1399-1403. https://doi.org/10.3168/jds. S0022-0302(05)72807-1.

Graham, C., and N. L. Simmons. 2005. Functional organization of the bovine rumen epithelium. Am. J. Physiol. Regul. Integr. Comp. Physiol. 288:R173-R181. https://doi.org/10.1152/ ajpregu.00425.2004. 
Gutknecht, J. 1987. Proton/hydroxide conductance through phospholipid bilayer membranes: Effects of phytanic acid. Biochim. Biophys. Acta 898:97-108.

Heller, F., P. Florian, C. Bojarski, J. Richter, M. Christ, B. Hillenbrand, J. Mankertz, A. H. Gitter, N. Burgel, M. Fromm, M. Zeitz, I. Fuss, W. Strober, and J. D. Schulzke. 2005. Interleukin-13 is the key effector Th2 cytokine in ulcerative colitis that affects epithelial tight junctions, apoptosis, and cell restitution. Gastroenterology 129:550-564. https://doi.org/10.1016/j.gastro.2005.05.002.

Hirst, B. H. 1989. The gastric mucosal barrier. Pages 279-308 in Handbook of Physiology: A Critical, Comprehensive Presentation of Physiological Knowledge and Concepts. Section 6: The Gastrointestinal System. Vol. 3: Salivary, Gastric, Pancreatic, and Hepatobiliary Secretion. S. G. Schultz, J. G. Forte, and B. B. Rauner, ed. Am. Physiol. Soc., Bethesda, MA.

Kirschner, N., and J. M. Brandner. 2012. Barriers and more: Functions of tight junction proteins in the skin. Ann. N. Y. Acad. Sci 1257:158-166. https://doi.org/10.1111/j.1749-6632.2012.06554.x.

Kirschner, N., P. Houdek, M. Fromm, I. Moll, and J. M. Brandner. 2010. Tight junctions form a barrier in human epidermis. Eur. J. Cell Biol. 89:839-842. https://doi.org/10.1016/j.ejcb.2010.07.010.

Kirschner, N., C. Poetzl, P. von den Driesch, E. Wladykowski, I. Moll, M. J. Behne, and J. M. Brandner. 2009. Alteration of tight junction proteins is an early event in psoriasis: Putative involvement of proinflammatory cytokines. Am. J. Pathol. 175:1095-1106. https://doi.org/10.2353/ajpath.2009.080973.

Kleen, J. L., G. A. Hooijer, J. Rehage, and J. P. Noordhuizen. 2003. Subacute ruminal acidosis (SARA): A review. J. Vet. Med. A Physiol. Pathol. Clin. Med. 50:406-414.

Klevenhusen, F., M. Hollmann, L. Podstatzky-Lichtenstein, R Krametter-Frötscher, J. R. Aschenbach, and Q. Zebeli. 2013. Feeding barley grain-rich diets altered electrophysiological properties and permeability of the ruminal wall in a goat model. J. Dairy Sci. 96:2293-2302. https://doi.org/10.3168/jds.2012-6187.

Leonhard-Marek, S., F. Stumpff, and H. Martens. 2010. Transport of cations and anions across forestomach epithelia: Conclusions from in vitro studies. Animal 4:1037-1056. https://doi.org/10.1017/ S1751731110000261.

Liu, J. H., T. T. Xu, Y. J. Liu, W. Y. Zhu, and S. Y. Mao. 2013. A high-grain diet causes massive disruption of ruminal epithelial tight junctions in goats. Am. J. Physiol. Regul. Integr. Comp. Physiol. 305:R232-R241. https://doi.org/10.1152/ajpregu.00068.2013.

Markov, A. G., J. R. Aschenbach, and S. Amasheh. 2015. Claudin clusters as determinants of epithelial barrier function. IUBMB Life 67:29-35. https://doi.org/10.1002/iub.1347.

Martin, B. K. 1963. Accumulation of drug anions in gastric mucosal cells. Nature 198:896-897.

McCarthy, K. M., I. B. Skare, M. C. Stankewich, M. Furuse, S. Tsukita, R. A. Rogers, R. D. Lynch, and E. E. Schneeberger. 1996. Occludin is a functional component of the tight junction. J. Cell Sci. 109:2287-2298.

Mineta, K., Y. Yamamoto, Y. Yamazaki, H. Tanaka, Y. Tada, K. Saito, A. Tamura, M. Igarashi, T. Endo, K. Takeuchi, and S. Tsukita. 2011. Predicted expansion of the claudin multigene family. FEBS Lett. 585:606-612. https://doi.org/10.1016/j.febslet.2011.01.028.

Miyoshi, M., M. Usami, and A. Ohata. 2008. Short-chain fatty acids and trichostatin A alter tight junction permeability in human umbilical vein endothelial cells. Nutrition 24:1189-1198. https://doi. org/10.1016/j.nut.2008.06.012.

Morita, K., M. Furuse, K. Fujimoto, and S. Tsukita. 1999. Claudin multigene family encoding four-transmembrane domain protein components of tight junction strands. Proc. Natl. Acad. Sci. USA 96:511-516.

Nocek, J. E. 1997. Bovine acidosis: Implications on laminitis. J. Dairy Sci. 80:1005-1028.

Ohata, A., M. Usami, and M. Miyoshi. 2005. Short-chain fatty acids alter tight junction permeability in intestinal monolayer cells via lipoxygenase activation. Nutrition 21:838-847. https://doi. org/10.1016/j.nut.2004.12.004.

Owens, F. N., D. S. Secrist, W. J. Hill, and D. R. Gill. 1998. Acidosis in cattle: A review. J. Anim. Sci. 76:275-286.
Peng, L., Z. R. Li, R. S. Green, I. R. Holzman, and J. Lin. 2009. Butyrate enhances the intestinal barrier by facilitating tight junction assembly via activation of AMP-activated protein kinase in Caco-2 cell monolayers. J. Nutr. 139:1619-1625. https://doi.org/10.3945/ jn.109.104638.

Penner, G. B., J. R. Aschenbach, G. Gabel, R. Rackwitz, and M. Oba 2009. Epithelial capacity for apical uptake of short chain fatty acids is a key determinant for intraruminal $\mathrm{pH}$ and the susceptibility to subacute ruminal acidosis in sheep. J. Nutr. 139:1714-1720. https://doi.org/10.3945/jn.109.108506.

Penner, G. B., K. A. Beauchemin, and T. Mutsvangwa. 2007. Severity of ruminal acidosis in primiparous Holstein cows during the periparturient period. J. Dairy Sci. 90:365-375. https://doi. org/10.3168/jds.S0022-0302(07)72638-3.

Penner, G. B., M. Oba, G. Gabel, and J. R. Aschenbach. 2010. A single mild episode of subacute ruminal acidosis does not affect ruminal barrier function in the short term. J. Dairy Sci. 93:48384845. https://doi.org/10.3168/jds.2010-3406.

Penner, G. B., M. A. Steele, J. R. Aschenbach, and B. W. McBride. 2011. Ruminant Nutrition Symposium: Molecular adaptation of ruminal epithelia to highly fermentable diets. J. Anim. Sci. 89:1108-1119. https://doi.org/10.2527/jas.2010-3378.

Plaizier, J. C., D. O. Krause, G. N. Gozho, and B. W. McBride 2008. Subacute ruminal acidosis in dairy cows: The physiological causes, incidence and consequences. Vet. J. 176:21-31. https://doi org/10.1016/j.tvjl.2007.12.016.

Plöger, S., F. Stumpff, G. B. Penner, J. D. Schulzke, G. Gäbel, H. Martens, Z. Shen, D. Günzel, and J. R. Aschenbach. 2012. Microbial butyrate and its role for barrier function in the gastrointestinal tract. Ann. N. Y. Acad. Sci. 1258:52-59. https://doi org/10.1111/j.1749-6632.2012.06553.x.

Raleigh, D. R., A. M. Marchiando, Y. Zhang, L. Shen, H. Sasaki, Y. Wang, M. Long, and J. R. Turner. 2010. Tight junction-associated MARVEL proteins marveld3, tricellulin, and occludin have distinct but overlapping functions. Mol. Biol. Cell 21:1200-1213. https://doi.org/10.1091/mbc.E09-08-0734.

Saitou, M., M. Furuse, H. Sasaki, J. D. Schulzke, M. Fromm, H. Takano, T. Noda, and S. Tsukita. 2000. Complex phenotype of mice lacking occludin, a component of tight junction strands. Mol. Biol. Cell 11:4131-4142.

Schulzke, J. D., S. Ploeger, M. Amasheh, A. Fromm, S. Zeissig, H. Troeger, J. Richter, C. Bojarski, M. Schumann, and M. Fromm. 2009. Epithelial tight junctions in intestinal inflammation. Ann. N. Y. Acad. Sci. 1165:294-300. https://doi.org/10.1111/j.17496632.2009.04062.x.

Steele, M. A., O. AlZahal, S. E. Hook, J. Croom, and B. W. McBride. 2009. Ruminal acidosis and the rapid onset of ruminal parakeratosis in a mature dairy cow: A case report. Acta Vet. Scand. 51:39. https://doi.org/10.1186/1751-0147-51-39.

Steele, M. A., J. Croom, M. Kahler, O. AlZahal, S. E. Hook, K. Plaizier, and B. W. McBride. 2011. Bovine rumen epithelium undergoes rapid structural adaptations during grain-induced subacute ruminal acidosis. Am. J. Physiol. Regul. Integr. Comp. Physiol. 300:R1515-R1523. https://doi.org/10.1152/ajpregu.00120.2010.

Stumpff, F., M. I. Georgi, L. Mundhenk, I. Rabbani, M. Fromm, H. Martens, and D. Günzel. 2011. Sheep rumen and omasum primary cultures and source epithelia: Barrier function aligns with expression of tight junction proteins. J. Exp. Biol. 214:2871-2882. https://doi.org/10.1242/jeb.055582.

Stumpff, F., H. Martens, S. Bilk, J. R. Aschenbach, and G. Gäbel 2009. Cultured ruminal epithelial cells express a large-conductance channel permeable to chloride, bicarbonate, and acetate. Pflugers Arch. 457:1003-1022. https://doi.org/10.1007/s00424-008-0566-6.

Sutton, J. D., M. S. Dhanoa, S. V. Morant, J. France, D. J. Napper, and E. Schuller. 2003. Rates of production of acetate, propionate, and butyrate in the rumen of lactating dairy cows given normal and low-roughage diets. J. Dairy Sci. 86:3620-3633. https://doi. org/10.3168/jds.S0022-0302(03)73968-X.

Szemeredy, G., and R. Raul. 1976. Alterations of the ruminal mucosa and its relation to the hepatic abscesses in bulls fed high energy and low fibre diets. Acta Vet. Acad. Sci. Hung. 26:313-324. 
Tadepalli, S., S. K. Narayanan, G. C. Stewart, M. M. Chengappa, and T. G. Nagaraja. 2009. Fusobacterium necrophorum: A ruminal bacterium that invades liver to cause abscesses in cattle. Anaerobe 15:36-43. https://doi.org/10.1016/j.anaerobe.2008.05.005.

Tanaka, H., M. Takechi, H. Kiyonari, G. Shioi, A. Tamura, and S. Tsukita. 2015. Intestinal deletion of Claudin-7 enhances paracellular organic solute flux and initiates colonic inflammation in mice. Gut 64:1529-1538. https://doi.org/10.1136/gutjnl-2014-308419.

Van Itallie, C., C. Rahner, and J. M. Anderson. 2001. Regulated expression of claudin- 4 decreases paracellular conductance through a selective decrease in sodium permeability. J. Clin. Invest. 107:1319-1327. https://doi.org/10.1172/JCI12464.

Van Itallie, C. M., and J. M. Anderson. 2006. Claudins and epithelial paracellular transport. Annu. Rev. Physiol. 68:403-429. https:// doi.org/10.1146/annurev.physiol.68.040104.131404.
Zebeli, Q., J. R. Aschenbach, M. Tafaj, J. Boguhn, B. N. Ametaj, and W. Drochner. 2012. Invited review: Role of physically effective fiber and estimation of dietary fiber adequacy in high-producing dairy cattle. J. Dairy Sci. 95:1041-1056. https://doi.org/10.3168/ jds.2011-4421.

Zeissig, S., N. Burgel, D. Günzel, J. Richter, J. Mankertz, U. Wahnschaffe, A. J. Kroesen, M. Zeitz, M. Fromm, and J. D. Schulzke. 2007. Changes in expression and distribution of claudin-2, -5 and -8 lead to discontinuous tight junctions and barrier dysfunction in active Crohn's disease. Gut 56:61-72. https://doi.org/10.1136/ gut.2006.094375. 